\title{
STUDI OPTIMASI PENENTUAN Cu(II) \\ DENGAN MENGGUNAKAN KALKON SEBAGAI PENGOMPLEK \\ SECARA VOLTAMMETRI STRIPPING ADSORPTIF (AdSV)
}

\author{
Deswati $^{1}$, Hamzar Suyani ${ }^{1}$, Bustanul Arifin ${ }^{1}$, Imelda $^{1}$ dan Yunita Salamah ${ }^{2}$ \\ ${ }^{1}$ Staf Pengajar Jurusan Kimia Universitas Andalas \\ ${ }^{2}$ Alumni Jurusan Kimia Universitas Andalas
}

\begin{abstract}
The research about determination of $\mathrm{Cu}$ (II) by adsorptive stripping voltammetry (AdSV) was conducted. AdSV method was applied to the determination of copper in ultra trace concentration. The parameters of ligand, accumulation potential, accumulation time, $\mathrm{pH}$ and ligand concentration was studied. Calcon was found as complexing agent that give the highest peak current. The optimum condition are accumulation potential $-0,7 \mathrm{~V}$, accumulation time $60 \mathrm{~s}$, $\mathrm{pH} 10$, and calcon concentration $0.12 \mathrm{mM}$. The relative standar deviation $(\mathrm{n}=8)$ at $10 \mu \mathrm{g} / \mathrm{L}$ standard concentration were obtained 4,27\%. This method was applied to determination of $\mathrm{Cu}$ (II) in sample from Batang Air Dingin, Lubuk Minturun and Muara Padang. The sample concentration were $4,778 \mu \mathrm{g} / \mathrm{L}$ and $5,189 \mu \mathrm{g} / \mathrm{L}$ for Batang Air Dingin and Muara Padang, respectively. The recovery of this method was studied for sample from Muara Padang and $98,31 \%$ was obtained.
\end{abstract}

Key words : Adsorptive, Stripping, Voltammetry, Calcon and Copper

\section{DAFTAR PUSTAKA}

1. Anonim, Pencemaran Logam Berat Juga Terdapat Dalam Makanan. (http://www.berbagisehat.com/index.php /artcles/food-a-nutrition/214pencemaran-logam-berat-juga-bisaterdapat-dalam-makanan.html) Februari 2009 pukul 9.22 WIB).

2. Anonim, Gangguan Gizi pada Autisme.(http://www.infosehat.com/inde x.php/artcls/info-gangguan-gizi-padaautisme.html) (13 Juni 2009).

3. Kepmenkes RI. 2002. Nomor 907/MENKES/SK/VII/2002 tentang Syarat-syarat dan Pengawas Kualitas Air Minum.

4. P. Gunkel, B. Fabre, G. Pardo, and J. Y. Baliteau, Ion Chromatographic and voltammetric determination of heavy metals in soils. Comparison with atomic emission spectroscopy, Analysis, 27, 823-828, (1999).

5. P. ProttiAmel Electrochemistry, Introduction to Modern Voltammetric and Polarographic Analysis Techniques, IV Edition, (2001).

6. R Kalvoda, and M. Kopanica, Adsorptive Stripping Voltammetry In Trace Analysis, Pure \& Appl. Chem., 61, 97-112, (1989).

7. A. Babaei, E. Shams, and A. Samadzadeh. Simultaneous Determination of Copper, Bismuth and Lead by Adsorptive Stripping Voltammetry in the Presence of Thymolphtalexone. Anal. Sci, 22, 95595, (2006).

8. A. A. Ensafi, S. Abbasi, H. R. Mansour and I. M. Baltork. Differential Pulse Adsorption Stripping Voltammetric Determina -tion of Copper(II) with 2Mercaptobenzimidazol at a Hanging Mercury-Drop Electrode, Anal. Sci, 12, 609-612, (2001).

9. S. M. Khopkar, Konsep dasar kimia analitik, UI-Press, Jakarta (1990).

10. H. A. Strobel and W.R. Heinemann. Chemical instrumention, a systematis approach, $3^{\text {rd }}$ ed., John Willey and Sons, New York, (1989). 
11. M. K Amini, and M. Kabiri. Determination of trace amounts of nickel by differential pulse adsorptive cathodic stripping voltmmetry using calconcarboxylic acid as a chelating agent, Journal of the Iranian Chemical Society, 2 : 32-39, (2005).

12. T. M. Acilesta, Pengaruh dan konsentrasi pengompleks dalam penentuan nikel (II) secara voltammetri stripping adsorptive, Skripsi Sarjana Kimia Universitas Andalas, Padang. (2008).
13. M. Korolezuk., Adsorptive stripping voltammetry of nickel and cobalt at in situ plated lead film electrode, Electrochem Commun, 7 : 1185-1189. (2005).

14. R. Jugade. and A.P. JoshiHighly sensitive adsorptive stripping voltammetric method for the ultra trace determination of chromium(VI)., Anal Sci, 22 : 571-574, (2006). 